\title{
Regulation of Pear Color Development in Relation to Activity of Flavonoid Enzymes
}

\author{
W.J. Steyn, ${ }^{1}$ D.M. Holcroft, 2 S.J.E. Wand, and G. Jacobs \\ Department of Horticultural Science, University of Stellenbosch, Private Bag X1, Matieland 7602, South Africa
}

AdDitional INDEX words. Pyrus communis, anthocyanin, phenylalanine ammonia-lyase, UDPGalactose: flavonoid-3-o-glycosyltransferase, low temperature, fruit development

\begin{abstract}
Changes in activity of phenylalanine ammonia-lyase (PAL) and UDPGalactose: flavonoid-3-o-glycosyltransferase (UFGT) during the development of pear (Pyrus communis L.) fruit and in response to cold fronts were assessed and related to changes in red color. Red and blushed pear cultivars attained maximum redness and highest anthocyanin concentrations in immature fruit. Red color generally faded toward harvest. UFGT activity increased over fruit development and was apparently not limiting to color development. However, the fading of red color and the decreasing level of phenolic compounds toward harvest might relate to decreasing PAL activity. Skin color and enzyme activity in the red pear 'Bon Rouge' displayed little responsiveness to low temperatures. In contrast, low temperatures increased red color and activity of both PAL and UFGT in the blushed pear 'Rosemarie'. Consistent with the general pigmentation pattern described above, the effect of temperature on enzyme activity was much greater early during fruit development than in the week before harvest.
\end{abstract}

Downgrading due to insufficient red color has limited the profitability of blushed pears in South Africa (Huysamer, 1998). These pears are sought by consumers and demand higher prices than green or full red fruit. Progress with the production of blushed pear cultivars is impeded by a general lack of knowledge regarding the regulation of color development in pears. Few studies have been conducted on pear color development and these all focused on red cultivars where considerable red color remains at harvest despite a gradual reduction during maturation (Dussi et al., 1997).

Red and blushed pears acquire their red color from anthocyanins present in their peel (Francis, 1970). Biosynthesis of anthocyanins is well established, with the exception of a few enzymatic steps (Macheix et al., 1990). Conversion of phenylalanine to trans-cinnamate, mediated by phenylalanine ammonia-lyase (PAL), is the first committed step in the synthesis of phenolic compounds. PAL activity increases concomitantly with the accumulation of anthocyanin and other phenolic compounds in many plants, including apple fruit (Lister et al., 1996; Macheix et al., 1990). In one of the final steps of anthocyanin biosynthesis, UDPGalactose: flavonoid-3-o -glycosyltransferase (UFGT) catalyzes the attachment of a sugar to the anthocyanin aglycone, considerably increasing its stability. UFGT activity was strongly correlated with the accumulation of anthocyanin in maturing apples (Ju et al., 1995a, 1999; Lister et al., 1996) and grape berries (Boss et al., 1996).

Low temperatures induce red color development in many fruit crops, e.g., apples (Curry, 1997) as well as in vegetative tissues (Christie et al., 1994). High temperatures, on the other hand, are generally associated with poor red color of fruit (Haselgrove et al., 2000; Reay, 1999). PAL and other enzymes of anthocyanin biosynthesis were low temperature-inducible in different plant species (Christie et al., 1994; Leyva et al., 1995; Shvarts et al., 1997). Also,

Received for publication 13 Mar. 2003. Accepted for publication 24 Sept. 2003. This material is based on work supported by the National Research Foundation under grant number GUN: 2046844 and the Deciduous Fruit Producers Trust of South Africa. We also thank Pia Nel, Susan Agenbag, and Desiree de Koker for their assistance with pigment and enzyme analysis, Hortec and ARC InfruitecNietvoorbij for supplying meteorological data, and SummerCourt and Imibala Farms for donation of plant material. Any opinion, findings and conclusions or recommendations expressed in this material are those of the authors and do not necessarily reflect the views of the National Research Foundation.

'Corresponding author; e-mail wsteyn@sun.ac.za.

2Present address: DOLE Fresh Vegetables, P.O. Box 1759, Salinas, Calif. 93902. subjecting apples to low $\left(6\right.$ and $\left.10^{\circ} \mathrm{C}\right)$ compared to high $\left(>20^{\circ} \mathrm{C}\right)$ temperatures increased PAL activity and increased anthocyanin synthesis (Faragher, 1983; Tan, 1980). The effect of temperature on color development in pears has not been studied.

We conducted a study to determine the pigmentation patterns of red and blushed pear cultivars produced in South Africa together with the developmental and environmental regulation of color development. Changes in red color during fruit development and with the passing of cold fronts were assessed in a blushed and a red pear cultivar and related to changes in the activity of PAL and UFGT.

\section{Material and Methods}

Pigmentation Patterns during 2000-01. Weekly changes in red color, anthocyanin concentration, and levels of phenolics in fruit of the blushed pears 'Rosemarie', 'Flamingo', and 'Forelle', and the red pears 'Bon Rouge' and 'Red d'Anjou' were assessed. Fully exposed fruit were randomly selected from the western side of north to south rows in each of up to three orchards (15 fruit per orchard) in up to three production regions; Stellenbosch (lat. $33^{\circ} 58^{\prime}$ 'S long. $\left.18^{\circ} 50^{\prime} \mathrm{E}\right)$, Grabouw (lat. $34^{\circ} 10^{\prime}$ 'S, long. 19 $03^{\prime} \mathrm{E}$ ) and

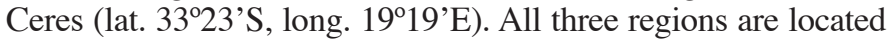
in the Western Cape Province (Mediterranean climate) of South Africa. In the case of 'Red d' Anjou' of which only one orchard was available, ten fruit were collected from each of three rows in the orchard. Although the orchards varied in age, all the trees were grafted on BP1 or BP3 rootstocks. Data collection commenced on 19 Oct. 2000, except for 'Bon Rouge', for which it started 2 weeks later due to later bloom and continued until commercial harvest (11 Jan. 2001 for 'Rosemarie' and 'Flamingo', 1 Feb. 2001 for 'Bon Rouge', 8 Feb. 2001 for 'Red d'Anjou' and 22 Feb. 2001 for 'Forelle').

Fruit were brought to the laboratory where color was measured with a chromameter (NR-3000; Nippon Denshoku, Tokyo, Japan) halfway between the calyx and stem ends. Although lightness, chroma and hue were recorded, only hue angle $\left(0^{\circ}=\right.$ red-purple, $90^{\circ}=$ yellow, $180^{\circ}=$ bluish-green and $270^{\circ}=$ blue) is presented as the most appropriate means to express differences in color in this study (McGuire, 1992). Whole fruit were peeled with a potato peeler ( $\pm 1 \mathrm{~mm}$ thickness), peel was frozen in liquid nitrogen and 
kept at $-80^{\circ} \mathrm{C}$ until analysis. Linear regression analysis was used to describe changes in anthocyanin concentration $\left(\mu \mathrm{g}^{\cdot} \mathrm{g}^{-1}\right.$ fresh weight), flavonol glycosides (A $350 \mathrm{~nm}$ ) and other phenolics (A $280 \mathrm{~nm}$ ) that occurred during fruit development.

Pigmentation Patterns AND ENZYMe aCtivity dURING 2001-02. Changes in hue of 50 'Rosemarie', 'Forelle', 'Flamingo' and 'Bon Rouge' pears in orchards (one of each cultivar) grafted on BP1 rootstock and established in the Stellenbosch region were assessed over the course of fruit development. Fully exposed fruit on the western side of trees were tagged on 31 Oct. 2001 and color measured weekly at their reddest position.

Using tagged fruit as reference to color, 10 fully exposed fruit were picked weekly before $1000 \mathrm{HR}$ from the western side of each of three adjacent rows in both the 'Rosemarie' and 'Bon Rouge' orchards to quantify changes in PAL and UFGT activity. Collection of fruit started on 31 Oct. 2001, 24 and 42 d after full bloom of 'Bon Rouge' and 'Rosemarie', respectively, and continued until 9 Jan. 2002, a week before commercial harvest. Color was measured at the reddest position on the fruit. Fruit were peeled and the peel was kept as described above. Peels of all the fruit of a row were pooled to obtain three replications.

EFFECT OF TEMPERATURE ON COLOR DEVELOPMENT. Color of 'Rosemarie', 'Flamingo', 'Forelle' and 'Bon Rouge' pears was measured daily at the reddest position on the fruit and correlated with temperature data obtained for the Nietvoorbij automatic weather station (within $4 \mathrm{~km}$ from the trial sites). PAL and UFGT activities in 'Rosemarie' and 'Bon Rouge' peel were assessed twice during fruit development with the passing of cold fronts. Using tagged fruit as reference, 10 fully exposed fruit were picked before $1000 \mathrm{HR}$ from the western side of each of three adjacent rows in the 'Rosemarie' and 'Bon Rouge' orchard on five sample dates early during fruit development (19 to 23 Nov. 2001) and again on four sample dates in the week before harvest ( 6 to 9 Jan. 2002). Collection of fruit started before the onset of frontal weather and continued until temperatures returned to prefrontal levels. Color was measured at the reddest position whereafter whole fruit were peeled and peel stored as described. Enzyme activity was correlated with temperature data obtained for the Nietvoorbij automatic weather station.

Pigment analysis. Pigments were extracted in $10 \mathrm{~mL} \mathrm{100 \%}$ acetone for $1 \mathrm{~h}$ at $4{ }^{\circ} \mathrm{C}$ and the extract decanted after centrifugation for $10 \mathrm{~min}$ at $10,000 \mathrm{~g}_{\mathrm{n}}$. The extract was rotary-evaporated and taken up in 1 to $2 \mathrm{~mL}$ (depending on the cultivar) of $5 \%(\mathrm{v} / \mathrm{v})$ formic acid in methanol. After filtration through $0.45 \mu \mathrm{m}$ filters (Millex-HV;
Millipore Corporation, Milford, Mass.), pigments were quantified via reverse-phase high performance liquid chromatography (HP 1100; Agilent Technologies, Palo Alto, Calif.). $\mathrm{A} \mathrm{C}_{18}$ column (250 $\times 4.6 \mathrm{~mm}$ with $5 \mu \mathrm{m}$; Spherisorb; Phase Separations, Deeside, U.K.), with a $12.5 \mathrm{~mm} 5 \mu \mathrm{m}$ guard column (Zorbax SB-C18; Agilent Technologies, Palo Alto, Calif.) was maintained at $30{ }^{\circ} \mathrm{C}$. The mobile phase consisted of 5\% formic acid in water (A) and $5 \%$ formic acid in methanol (B) with a linear gradient of $25 \%$ to $65 \%$ during the first $18 \mathrm{~min}$ and from $65 \%$ to $100 \%$ during the last $3 \mathrm{~min}$. The flow rate was $1.0 \mathrm{~mL} \cdot \mathrm{min}^{-1}$, with an injection volume of 10 or $15 \mu \mathrm{L}$, depending on the cultivar. Eluted anthocyanins were monitored at $530 \mathrm{~nm}$. Chromatographs indicated the presence of two anthocyanin pigments in all pear cultivars studied. The major pigment co-eluted with cyanidin 3-galactoside. The minor pigment is considered to be either cyanidin 3-arabinoside (Francis, 1970) or peonidin 3-galactoside (Dussi et al., 1995). Both anthocyanins were quantified using a standard curve obtained with idaein chloride (cyanidin 3-galactoside) (Carl Roth, Karlsruhe, Germany). Eluted phenolics were monitored at 280 and $350 \mathrm{~nm}$. Chromatographs indicated the presence of several peaks, many of which were present at both 280 and $350 \mathrm{~nm}$. Flavonol glycosides were assessed by adding up the absorbance units of peaks that only occurred or had their higher absorbance at $350 \mathrm{~nm}$ (Lister et al., 1994). Other phenolics were assessed by adding up the absorbance units of peaks that only occurred or had their higher absorbance at $280 \mathrm{~nm}$.

ENZYME EXTRACTION AND ASSAY OF ACTIVITY. The method of Lister et al. (1996) was used for enzyme extraction from $20 \mathrm{~g}$ samples of ground tissue. The protein concentration of the enzyme extract was determined by means of the dye-binding assay of Bradford (1976).

PAL activity in the enzyme extracts was assayed according to Lister et al. (1996) who in turn adapted the method of Zucker (1965). The method entails measuring the yield of cinnamic acid from L-phenylalanine upon addition of the enzyme extract. Enzyme activity was expressed as pkat $\cdot \mathrm{mg}^{-1}$ protein, where $1 \mathrm{~kat}$ is the amount of enzyme required to produce $1 \mathrm{~mol} \cdot \mathrm{s}^{-1}$ trans-cinnamic acid under the assay conditions.

The procedure of Lister et al. (1996) was used to assay UFGT activity. Formation of quercetin 3 -galactose was quantified by HPLC using the same methodology as described for anthocyanins, but with an injection volume of $5 \mu \mathrm{L}$. Quercetin-3-galactoside eluted at $\approx 12.5 \mathrm{~min}$ and was detected at $350 \mathrm{~nm}$. UFGT activity was expressed as pkat $\cdot \mathrm{mg}^{-1}$ protein.

Table 1. Hue and anthocyanin concentration of red ('Red d'Anjou' and 'Bon Rouge') and blushed ('Forelle', 'Flamingo' and 'Rosemarie') pear cultivars as measured during the 2000-01 season. Statistical analysis for anthocyanin concentration was also done for blushed cultivars alone since the very high anthocyanin concentrations in red cultivars concealed differences between blushed cultivars when analyzed together.

\begin{tabular}{|c|c|c|c|c|c|c|c|}
\hline \multirow[b]{2}{*}{ Cultivar } & \multicolumn{4}{|c|}{ Hue $\left({ }^{\circ}\right)^{z}$} & \multicolumn{3}{|c|}{ Anthocyanin concn $\left(\mu \mathrm{g} \cdot \mathrm{g}^{-1}\right.$ fresh wt) } \\
\hline & Lowest & Highest & Harvest & SD & Highest & Lowest & Harvest \\
\hline \multicolumn{8}{|l|}{$\overline{\text { Red }}$} \\
\hline Red d'Anjou & $5.2 \mathrm{a}^{\mathrm{y}}$ & $16.2 \mathrm{a}$ & $13.6 \mathrm{a}$ & $3.24 \mathrm{a}$ & $295.4 \mathrm{a}$ & $189.0 \mathrm{a}$ & $188.4 \mathrm{a}$ \\
\hline \multicolumn{8}{|l|}{ Blushed } \\
\hline Forelle & $23.6 \mathrm{a}$ & $44.9 \mathrm{a}$ & $34.5 \mathrm{a}$ & $11.1 \mathrm{a}$ & $18.4 \mathrm{a}$ & $3.2 \mathrm{~b}$ & $10.5 \mathrm{a}$ \\
\hline Flamingo & $19.7 \mathrm{a}$ & $52.5 \mathrm{a}$ & $52.5 \mathrm{~b}$ & $15.1 \mathrm{~b}$ & $14.6 \mathrm{ab}$ & $4.5 \mathrm{a}$ & $5.3 \mathrm{~b}$ \\
\hline \multicolumn{8}{|l|}{ Contrasts } \\
\hline Within red & 0.0291 & 0.0084 & 0.0241 & 0.0028 & 0.0125 & 0.0001 & 0.0008 \\
\hline Within blushed & 0.0001 & 0.0001 & 0.0001 & 0.0009 & 0.0072 & 0.0031 & 0.0069 \\
\hline Red vs. blushed & 0.0001 & 0.0001 & 0.0001 & 0.0001 & 0.0001 & 0.0001 & 0.0001 \\
\hline
\end{tabular}

${ }^{2} 0^{\circ}=$ red-purple, $90^{\circ}=$ yellow, $180^{\circ}=$ bluish-green, and $270^{\circ}=$ blue.

y Means in columns and within groups were separated by LSD $(5 \%)$. 
StatistiCal analysis. The data were analyzed with the General Linear Models (GLM), Linear Regression (REG) and Correlation (CORR) procedures of SAS (SAS release 6.12P; SAS Institute, 1996, Cary, N.C.).

\section{Results and Discussion}

Pigmentation Patterns. Red and blushed pearcultivars included in our study varied considerably in anthocyanin concentration and red color (Table 1; Figs. 1 and 2). Although changes in hue were gradual in most cultivars, 'Rosemarie' color fluctuated from week to week (Fig. 2). Despite this, all cultivars displayed a similar general pigmentation pattern, which entailed the attainment of best red color and highest anthocyanin concentrations a month or more before harvest (Figs. 1 and 2) and a tendency of color to fade towards harvest (Fig. 2).

Though the pigmentation pattern described in this study is consistent with previous reports for various red pear cultivars (Dussi et al., 1997), it is contrary to most other crop species where maximum pigmentation and color is attained in ripe fruit (Macheix, 1990). Accumulation of anthocyanin towards maturity is thought to assist seed dispersal (Harborne, 1965). Function and ecological significance of the coloration pattern of pears is uncertain. However, it has to be considered that red and blushed cultivars are selected for aesthetic reasons, often from green parents, and that the increased
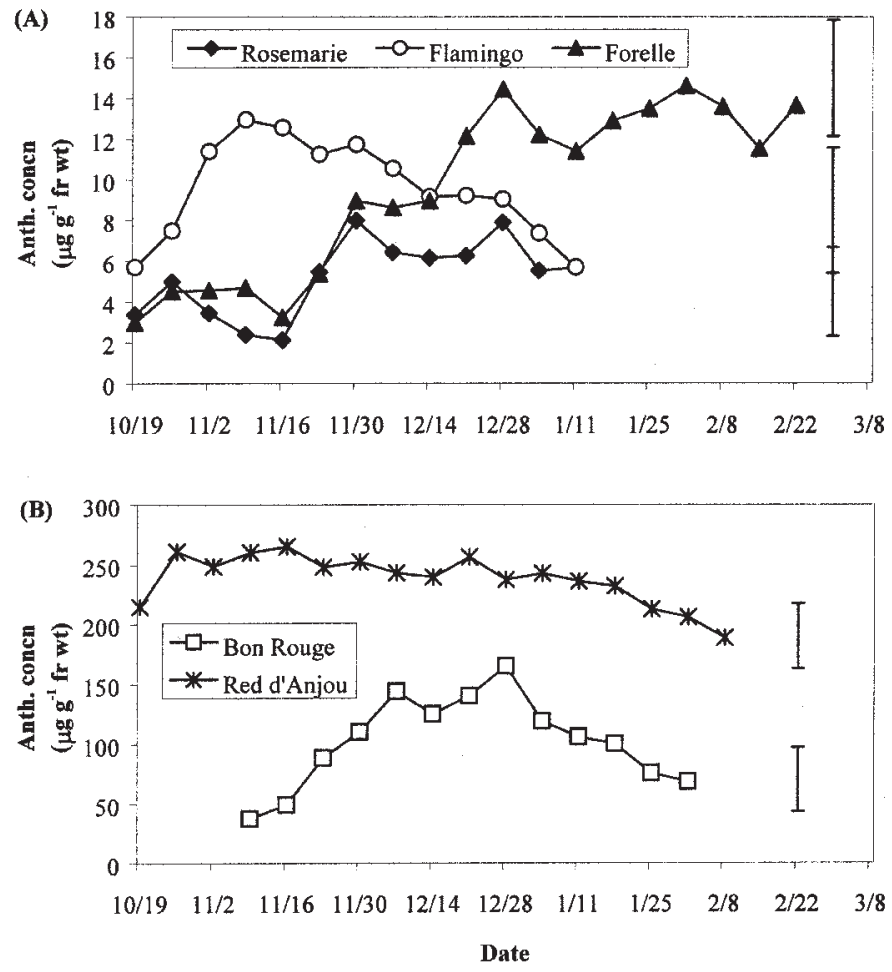

\begin{tabular}{lccc} 
& \multicolumn{3}{c}{ Contrast } \\
\cline { 2 - 4 } Cultivar & Linear & Quadratic & Cubic \\
\hline Red d'Anjou & 0.0068 & 0.0093 & 0.8182 \\
Bon Rouge & 0.1018 & 0.0001 & 0.4840 \\
Forelle & 0.0001 & 0.0262 & 0.0700 \\
Flamingo & 0.3744 & 0.0013 & 0.1691 \\
Rosemarie & 0.0001 & 0.4628 & 0.0008 \\
\hline
\end{tabular}

Fig. 1. Anthocyanin concentrations in red ('Red d'Anjou' and 'Bon Rouge') (A) and blushed ('Forelle', 'Flamingo' and 'Rosemarie') (B) pear peel during the $2000-01$ season. Vertical bars indicate LSD (5\%). pigmentation does not necessarily confer any adaptive advantage (Harborne, 1965). Dussi et al.(1997) described a 'Bartlett'mutation, 'Rosired Bartlett', in which red color increased toward harvest. This cultivar clearly emerged through a different mutation from that of 'Bon Rouge', which is also a 'Bartlett' mutation.

The red pears 'Bon Rouge' and 'Red d'Anjou' maintained higher anthocyanin concentrations during fruit development and were redder at harvest than the blushed pears 'Forelle', 'Flamingo', and 'Rosemarie' (Table 1). Among the blushed cultivars, 'Rosemarie' had the lowest anthocyanin concentration (Table 1). Standard deviation in the hue of the different cultivars over fruit development seemed to decrease as the maximum anthocyanin concentration attained by the respective cultivars increased (Table 1). Greater ability to accumulate anthocyanin increased the stability of red color over fruit development.

DEVElopMeNTAL REgUlation OF COLOR DEVELOPMENT. PAL activity decreased during fruit development in both 'Rosemarie' and 'Bon Rouge' (Fig. 3). This is consistent with previous findings in various kinds of fruit where PAL activity generally peaked in juvenile fruit whereafter it gradually decreased toward harvest (Macheix et al., 1990). PAL activity increases again in fruits that accumulate anthocyanin or other phenolics during maturation (Macheix et al., 1990). Fading of pear red color toward harvest could possibly relate to the diminished activity of PAL toward harvest (Fig. 3). However, anthocyanin synthesis in mature apples only required PAL activity if there were insufficient phenolic or flavonoid precursors brought about by etiolation (Ju et al., 1995b). In contrast, PALactivity was required for the reddening of maturing strawberry fruit (Given et al., 1988). In apples, high PAL activity in juvenile fruit corresponded with the first peak of anthocyanin synthesis (Ju et al., 1995b). In contrast, 'Rosemarie' and 'Bon Rouge' fruit color was relatively poor early during fruit development when PAL activity was highest (Fig. 3). High PAL activity in juvenile fruit is thought to facilitate the accumulation of large amounts of different phenolics and flavonoids required for protection against various stresses, e.g., UV-light, fungal infection and browsing (McClure, 1975). Therefore, although PAL activity is required for anthocyanin synthesis, it does not necessarily guarantee its synthesis since the

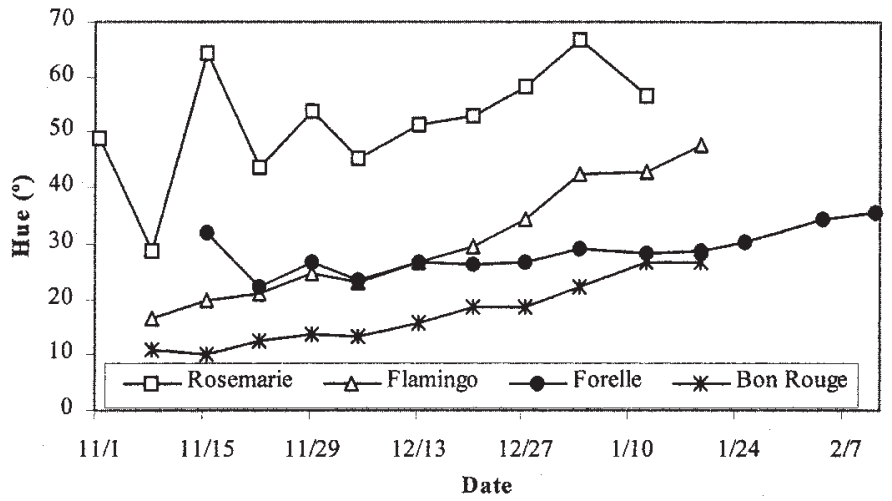

\begin{tabular}{lcc} 
Cultivar & $\mathrm{y}=\mathrm{xb}+\mathrm{a}$ & $\mathrm{y}=\mathrm{cx}^{2}+\mathrm{bx}+\mathrm{a}$ \\
\hline Bon Rouge & $0.93^{* * *}$ & $0.97^{* * *}$ \\
Forelle & $0.46^{*}$ & $0.72^{* *}$ \\
Flamingo & $0.94^{* * *}$ & $0.98^{* * *}$ \\
Rosemarie & 0.29 & 0.30 \\
\hline
\end{tabular}

Fig. 2. Hue angles for 'Bon Rouge', 'Forelle', 'Flamingo' and 'Rosemarie' pears during 2001-02. Color was repeatedly measured on 50 marked fruit of each cultivar. Hue angles, measured at the reddest position on fruit, fluctuate between $0^{\circ}$ (red-purple) and $90^{\circ}$ (yellow). ${ }^{* * * * * * * *} R^{2}$ significant at $P=0.05,0.01$, or 0.001 , respectively. 
cinnamic acid can be diverted into numerous other phenolic or flavonoid compounds (Lister et al., 1996).

Congruent with the position of PAL at the start of phenylpropanoid metabolism, levels of phenolic acids and flavonoids in fruit skin generally correlate with PAL activity (Lister et al., 1996; Macheix et al., 1990). Inhibition of PAL has been found to result in a comparable reduction in the phenolic content of 'Delicious' apples (Ju et al., 1995b). Since subsamples kept for determining anthocyanins and phenolics were lost due to malfunction of the $-80{ }^{\circ} \mathrm{C}$ freezer, we could not directly correlate enzyme activity with levels of different phenolics in the same fruit. However, absorbance at $280 \mathrm{~nm}$ steadily declined toward harvest in all the pear cultivars studied (Fig. 4). It is likely that these changes in the levels of phenolics relate to the decreasing activity of PAL (Fig. 3). Chlorogenic acid contributed most to absorbance at $280 \mathrm{~nm}$ (data not presented), hence, changes in absorbance primarily reflect changes in the concentration of this compound. Flavonol glycoside levels decreased toward harvest in 'Red d'Anjou', 'Bon Rouge' and 'Rosemarie' (Fig. 4B). In 'Forelle' and 'Flamingo' flavonol glycoside levels increased from low initial levels until the end of December whereafter it remained relatively constant until harvest. Evidently, a direct relationship between PAL activity and flavonoid glycoside levels seems less likely.

In contrast to PAL, UFGT activity increased during fruit development in both 'Rosemarie' and 'Bon Rouge' (Fig. 3) and was evidently not the rate-limiting step in synthesis or the reason for the fading of red color toward harvest in 'Rosemarie' or 'Bon Rouge'.

(A)

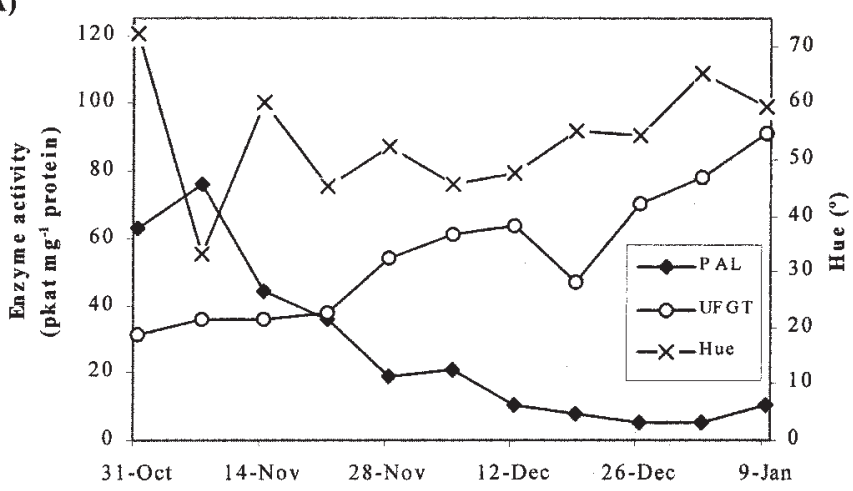

(B)

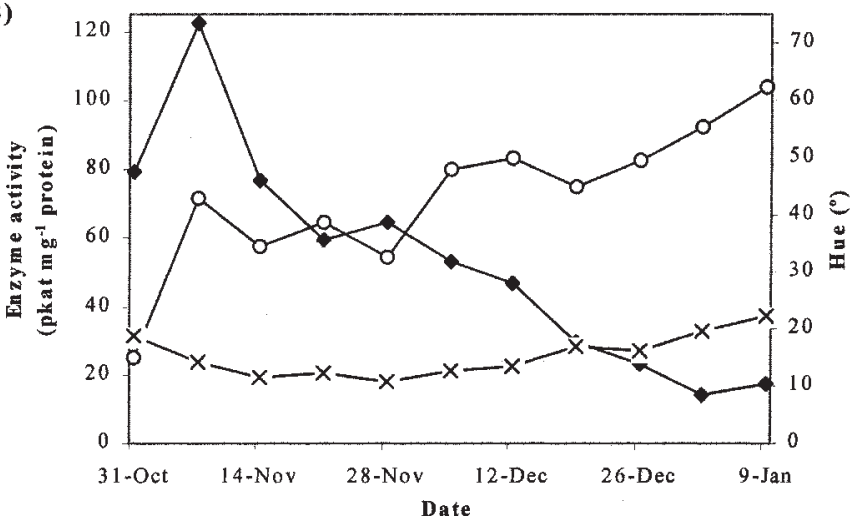

Fig. 3. Changes in the activity of phenylalanine ammonia-lyase (PAL), UDPGal: flavonoid-3-o-glycosyltransferase (UFGT) and hue in 'Rosemarie' (A) and 'Bon Rouge' (B) pears during 2001-02. Hue angles, measured at the reddest position on fruit, fluctuate between $0^{\circ}$ (red-purple) and $90^{\circ}$ (yellow). Means were separated by LSD (5\%). LSD values for PAL activity, UFGT activity and hue for 'Rosemarie' are $7.3,18.1$, and 8.5 , respectively. The respective LSD values for 'Bon Rouge' are 23.0, 18.5, and 3.3.
In contrast to our results, UFGT activity was strongly correlated with color development in maturing apples (Ju et al., 1995a, 1999; Lister et al., 1996) and grape berries (Boss et al., 1996). High basal activity of UFGT in green apple peel has been attributed to its ability to also catalyze synthesis of flavonol glycosides (Ju et al., 1995a, 1999). The inverse patterns of PAL and UFGT activity during fruit development of 'Bon Rouge' and 'Rosemarie' (Fig. 3) was contrary to previous observations in apple where these enzymes showed similar patterns of activity, thought to be indicative of coordinated regulation of anthocyanin synthesis (Lister et al., 1996).

Despite the apparently poor correlation between PALand UFGT activity and 'Rosemarie' and 'Bon Rouge' color, flux through the phenylpropanoid pathway appeared to be greater in the red 'Bon Rouge' compared to the blushed 'Rosemarie' fruit. PAL activity in 'Bon Rouge' was at least $40 \%$ and UFGT activity $10 \%$ to $20 \%$ higher throughout fruit development than in 'Rosemarie' (Fig. 3). Levels of flavonol glycosides and phenolic acids were also higher in red compared to blushed pear cultivars (Table 2; Fig. 4). Similarly, Lister et al. (1996) found that PAL and UFGT activity and synthesis of flavonoids were considerably higher in a red compared to a green apple cultivar.

The synthesis of anthocyanins and flavonol glycosides appeared to be separately regulated in the different pear cultivars. 'Rosemarie' and 'Flamingo', both selected from the progeny of crosses made
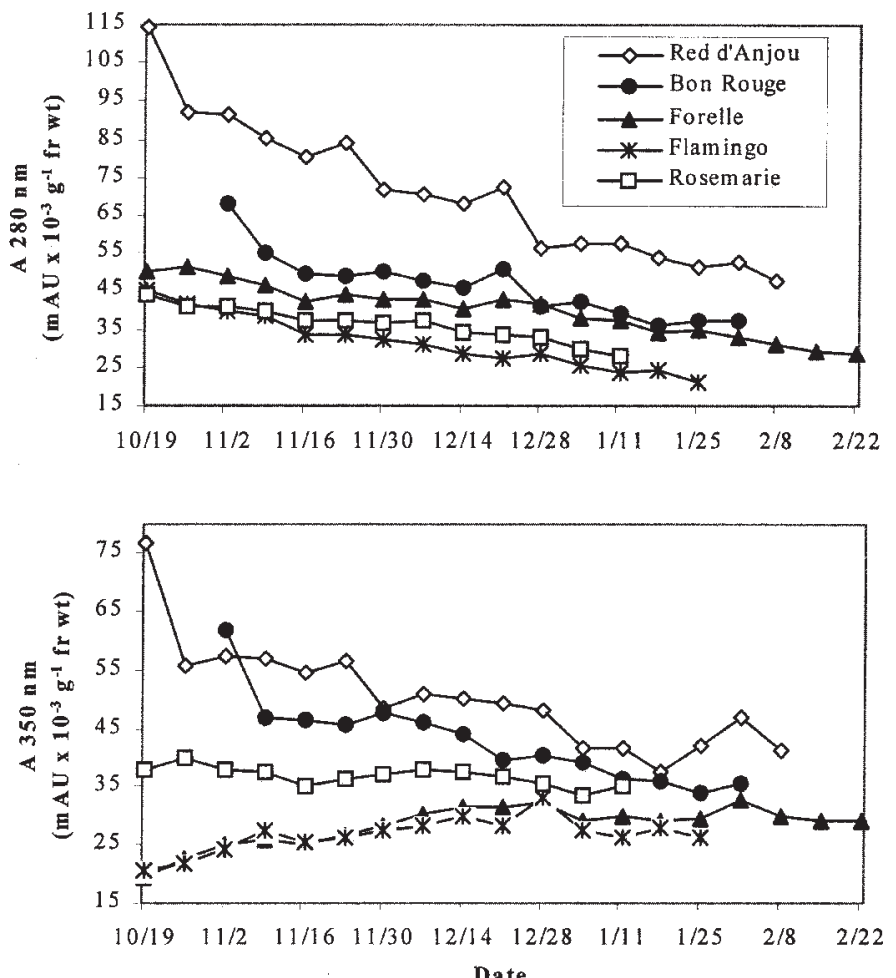

\begin{tabular}{lcccc} 
& $\mathrm{A} 280$ & & \multicolumn{2}{c}{$\mathrm{A} 350$} \\
\cline { 2 - 2 } \cline { 5 - 5 } Cultivar & $\mathrm{y}=\mathrm{xb}+\mathrm{a}$ & & $\mathrm{y}=\mathrm{xb}+\mathrm{a}$ & $\mathrm{y}=\mathrm{cx}^{2}+\mathrm{bx}+\mathrm{a}$ \\
\hline Red d'Anjou & $0.88^{* * *}$ & & $0.73^{* * *}$ & --- \\
Bon Rouge & $0.80^{* * *}$ & & $0.80^{* * *}$ & --- \\
Forelle & $0.87^{* * *}$ & & $0.77^{* * *}$ & $0.91^{* * *}$ \\
Flamingo & $0.95^{* * *}$ & & $0.53^{* *}$ & $0.76^{* * *}$ \\
Rosemarie & $0.95^{\text {*** }}$ & & $0.49^{* *}$ & --- \\
\hline
\end{tabular}

Fig. 4. Phenolic acids (A), and flavonol glycosides (B) in peel of 'Red d'Anjou', 'Bon Rouge', 'Forelle', 'Flamingo' and 'Rosemarie' pears during the 2000-01 season as inferred from absorbance readings at 280 and $350 \mathrm{~nm}$, respectively. ${ }^{*, * * * * * * *} R^{2}$ significant at $P=0.05,0.01$, or 0.001 , respectively. 
Table 2. Phenolic acids and flavonol glycosides in peel of red ('Red d'Anjou' and 'Bon Rouge') and blushed ('Forelle', 'Flamingo', and 'Rosemarie') pear cultivars during the 2000-01 season as inferred from absorbance readings at 280 and $350 \mathrm{~nm}$, respectively.

\begin{tabular}{lccccc}
\hline & \multicolumn{2}{c}{$\begin{array}{c}\text { Absorbance } \\
\text { at } 280 \mathrm{~nm} \\
(\mathrm{mAU} / \mathrm{g} \text { fresh } \mathrm{wt})\end{array}$} & & \multicolumn{2}{c}{$\begin{array}{c}\text { Absorbance } \\
\text { at } 350 \mathrm{~nm} \\
(\mathrm{mAU} / \mathrm{g} \text { fresh wt })\end{array}$} \\
\cline { 2 - 3 } \cline { 5 - 6 } Cultivar & $\begin{array}{c}\text { Highest } \\
\times 1000\end{array}$ & $\begin{array}{c}\text { Harvest } \\
\times 1000\end{array}$ & & $\begin{array}{c}\text { Highest } \\
\times 1000\end{array}$ & $\begin{array}{c}\text { Harvest } \\
\times 1000\end{array}$ \\
\hline Red d'Anjou & $156 \mathrm{a}^{\mathrm{z}}$ & $74.7 \mathrm{a}$ & & $76.5 \mathrm{a}$ & $41.1 \mathrm{a}$ \\
Bon Rouge & $110 \mathrm{~b}$ & $54.9 \mathrm{~b}$ & & $61.3 \mathrm{~b}$ & $33.7 \mathrm{~b}$ \\
Forelle & $63 \mathrm{c}$ & $39.7 \mathrm{c}$ & & $32.4 \mathrm{~d}$ & $30.1 \mathrm{bc}$ \\
Flamingo & $55 \mathrm{c}$ & $32.2 \mathrm{~d}$ & & $33.0 \mathrm{~d}$ & $26.4 \mathrm{c}$ \\
Rosemarie & $63 \mathrm{c}$ & $42.6 \mathrm{c}$ & & $43.1 \mathrm{c}$ & $34.6 \mathrm{~b}$ \\
\hline
\end{tabular}

${ }^{\mathrm{z}}$ Means in columns were separated by LSD (5\%).

between 'Bon Rouge' and 'Forelle' (ARC Infruitec-Nietvoorbij and SAPO, 1998), reached comparable hues and pigment concentrations at harvest (Table 1). However, immature 'Flamingo' fruit had a greater capacity to accumulate anthocyanin and did not display the weekly fluctuation in color evident in 'Rosemarie' (Fig. 2). In this regard, 'Flamingo' resembled 'Bon Rouge' while 'Rosemarie' apparently inherited its pigmentation pattern from 'Forelle'. Conversely, with regard to the levels of flavonol glycosides, 'Flamingo' resembled 'Forelle' while 'Rosemarie' resembled 'Bon Rouge' (Fig. 4B).

EFFECT OF TEMPERATURE ON COLOR DEVELOPMENT. 'Rosemarie' pears increased in redness with the passing of cold fronts while red color faded during intermittent warmer periods (Fig. 5). In contrast, 'Bon Rouge' color did not fluctuate in response to temperature. This difference in response was investigated further separately (unpublished data). In the current study, we assessed PAL and UFGT activity with the passing of two of these cold fronts, the
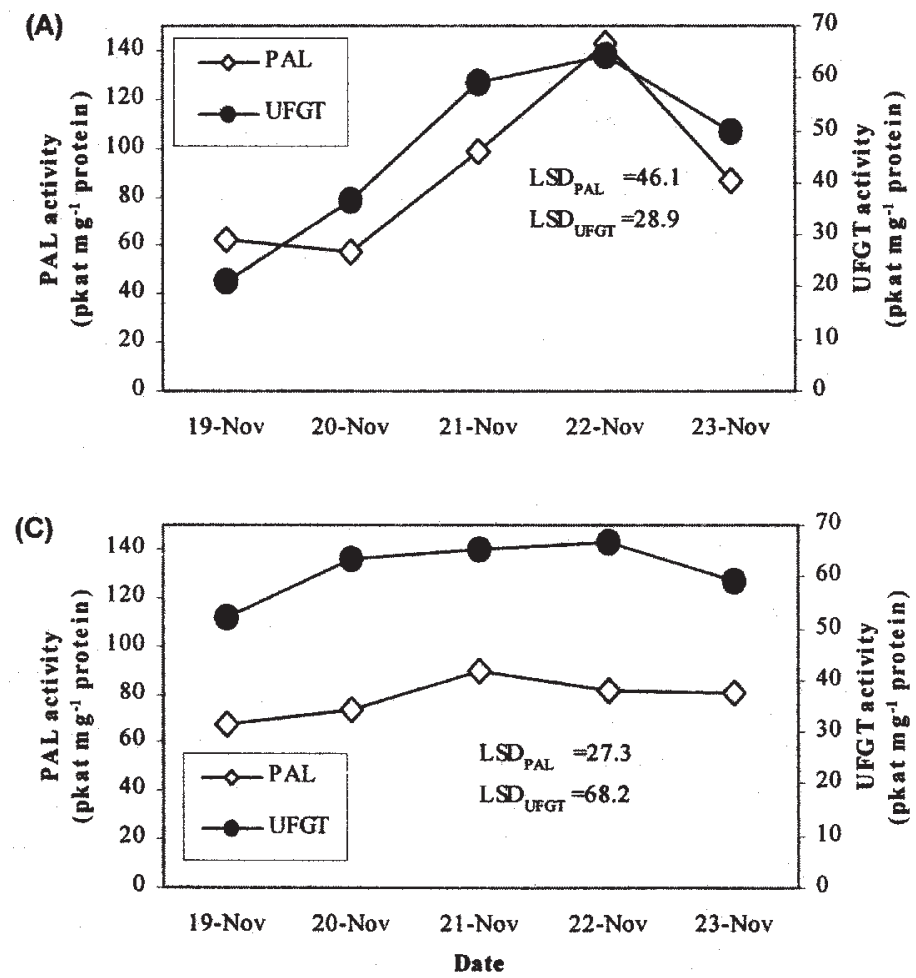
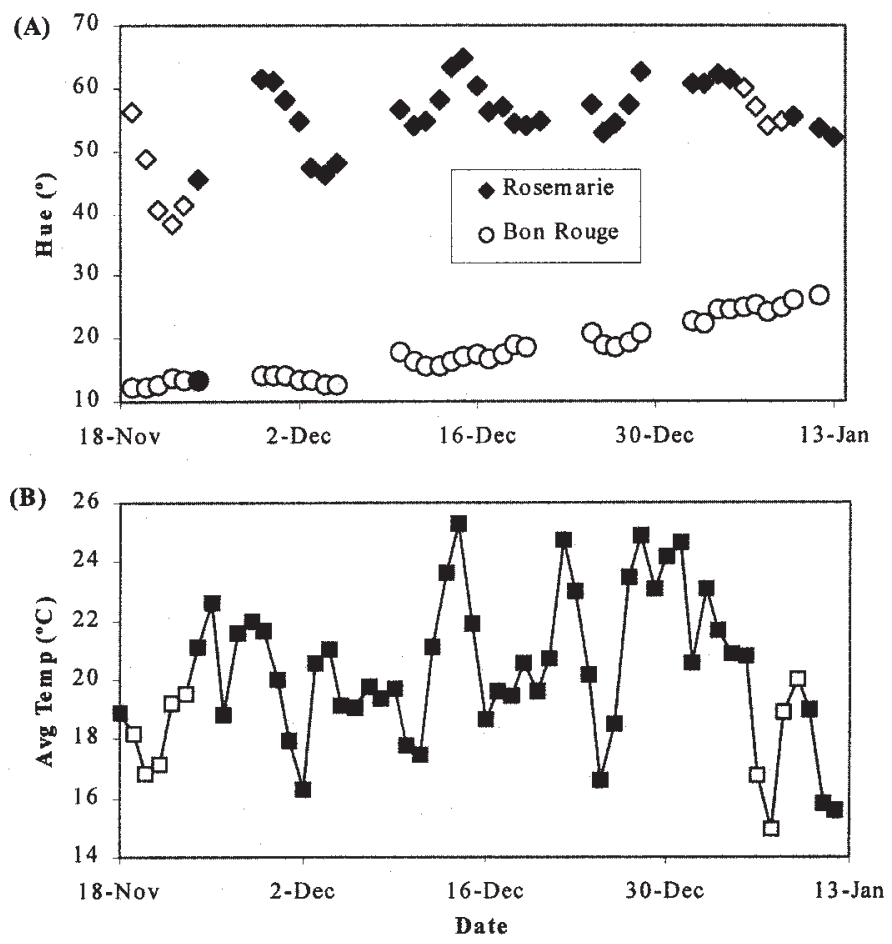

Fig. 5. (A) Daily changes in hue angle of 'Rosemarie' and 'Bon Rouge' pears during the 2001-02 season. Hue angles, measured at the reddest position on fruit, fluctuate between $0^{\circ}$ (red-purple) and $90^{\circ}$ (yellow). Average daily temperatures are presented in (B). PAL and UFGT activities were assessed on the days indicated by open symbols.

first during early fruit development and the second in the week before harvest (Fig. 5).

PAL and UFGT activity in 'Rosemarie' peel increased by $130 \%$
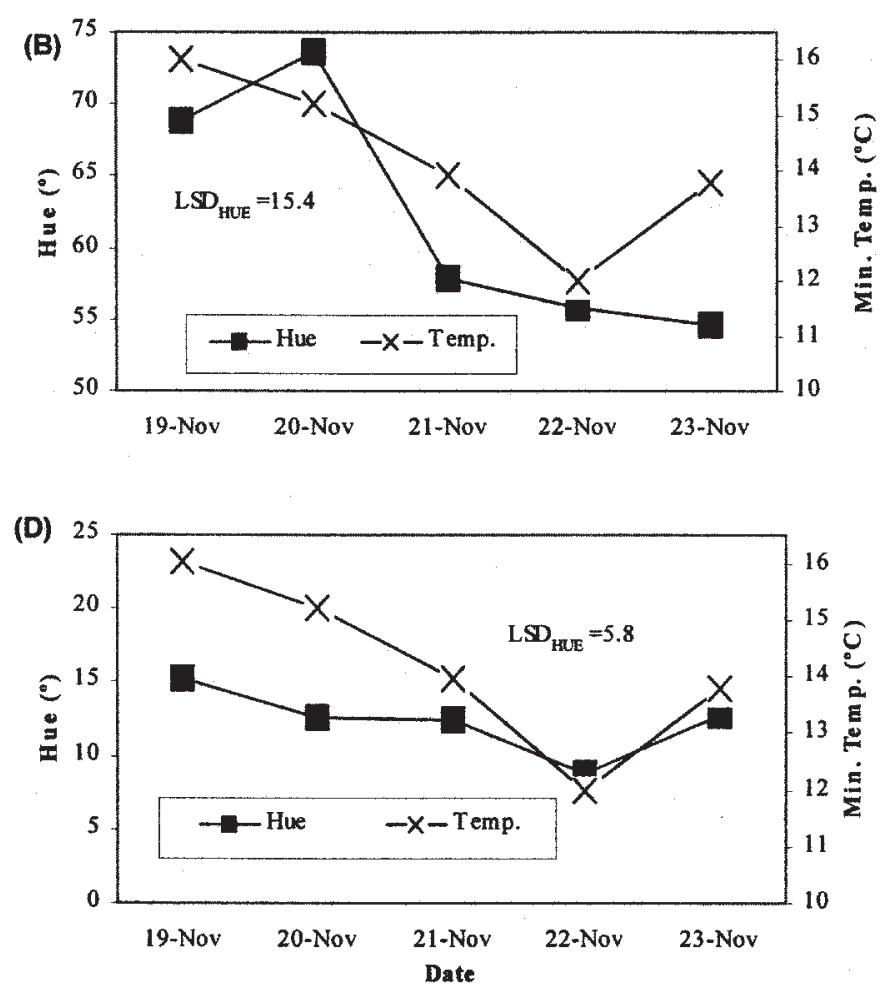

Fig. 6. Phenylalanine ammonia-lyase (PAL) and UDPGal:flavonoid-3-o-glycosyltransferase (UFGT) activity in 'Rosemarie' (A) and 'Bon Rouge' (B) peel during the passing of a cold front (19-23 Nov. 2001). Hue angles and minimum temperatures are also presented in (C) 'Rosemarie' and (D) 'Bon Rouge'. Hue angles, measured at the reddest position on fruit, fluctuate between $0^{\circ}$ (red-purple) and $90^{\circ}$ (yellow). 
Table 3. Correlation of phenylalanine ammonia-lyase (PAL) and UDPGal:flavonoid-3-o-glycosyltransferase (UFGT) activity in 'Rosemarie' and 'Bon Rouge' pear peel with hue and daily minimum temperatures recorded during the passing of cold fronts at an early stage of fruit development (19-23 Nov. 2001) and again in the week before harvest (6-9 Jan. 2002).

\begin{tabular}{|c|c|c|c|c|}
\hline & \multicolumn{2}{|c|}{ Rosemarie } & \multicolumn{2}{|c|}{ Bon Rouge } \\
\hline & PAL & UFGT & PAL & UFGT \\
\hline Daily minimum temperature & $-0.79^{* * *}$ & $-0.72^{* *}$ & -0.46 & -0.37 \\
\hline \multicolumn{5}{|l|}{ Cold front 2} \\
\hline Daily minimum temperature & 0.21 & $-0.60^{*}$ & 0.14 & 0.50 \\
\hline Hue & -0.11 & $-0.60^{*}$ & -0.32 & -0.51 \\
\hline
\end{tabular}

*,******Significant Pearson correlation coefficients at $P=0.05,0.01,0.001$, respectively; $\mathrm{N}=15 \mathrm{CF} 1, \mathrm{~N}=12 \mathrm{CF} 2$.

and $200 \%$, respectively, while hue decreased by $19^{\circ}$ in response to the first cold front (19 to 23 Nov.) (Fig. 6A and B). Activities of both enzymes strongly correlated with the lower minimum temperatures (Table 3). There was also a weaker, but significant correlation with hue. Activities of both enzymes decreased after the passing of the cold front, though the activity of UFGT was still $134 \%$ higher than prefrontal levels on 23 Nov. The cold front had no effect on 'Bon Rouge' color, though PAL activity was 33\% higher $(P=0.1)$ on 21 Nov. than on 19 Nov. (Fig. 6C and D). UFGT levels were $28 \%$ higher on 22 Nov. than on 19 Nov., but this increase was not statistically significant (Fig. 6C and D). Enzyme activities in 'Bon Rouge' did not correlate with hue or temperature (Table 3).

The second cold front brought about a greater reduction in temperature than the first (Fig. 7B and D). 'Rosemarie' hue decreased by nearly $14^{\circ}$ between 6 and 9 Jan. (Fig. 7B). UFGT activity was $11 \%$ higher on 9 Jan. than on 6 Jan., but the increase was not significant (Fig. 7A). UFGT activity was poorly correlated with minimum temperature and hue (Table 3 ). PAL activity was unaffected by the cold front (Fig. 7A). 'Bon Rouge' hue was variable, fluctuating between $18^{\circ}$ and $23^{\circ}$ (Fig. 7D). PAL activity in 'Bon
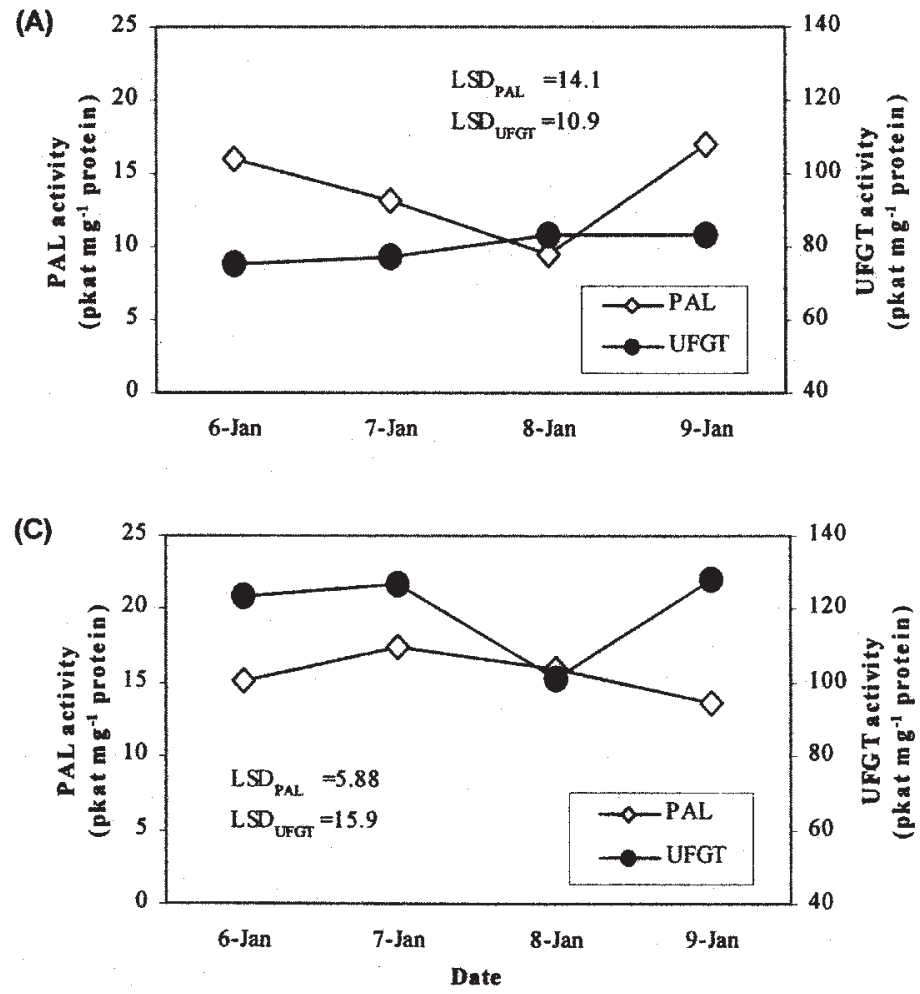

Rouge' did not respond to the cold front (Fig. 7C). The apparent reduction in UFGT activity in 'Bon Rouge' on 8 January is not readily explainable (Fig. 7C). However, enzyme activities in 'Bon Rouge' did not correlate with hue or temperature (Table 3).

The above results indicate that the activity of anthocyanin biosynthetic enzymes in 'Rosemarie' respond to temperature, at least early during fruit development. Anthocyanin structural and regulatory genes were previously found to be induced by low temperatures in various tissues of many different plants (Christie et al., 1994; Leyva et al., 1995; Shvarts et al., 1997). Faragher (1983) and Tan (1980) found much higher PAL activity and better red color development in apples held at low $\left(6\right.$ and $10^{\circ} \mathrm{C}$, respectively) compared to higher temperatures $\left(>20^{\circ} \mathrm{C}\right)$. Contrary to our results, anthocyanin synthesis benefited from low temperatures in all the different apple cultivars studied (Curry, 1997; Marais et al., 2001; Reay, 1999). Hence, the apparent lack of response of 'Bon Rouge' to low temperatures was rather surprising, although it could relate to its high anthocyanin concentration. Lancaster et al. (2000) found that apple fruit already containing high anthocyanin concentrations had a reduced ability to further accumulate anthocyanin at 10 and $20^{\circ} \mathrm{C}$.
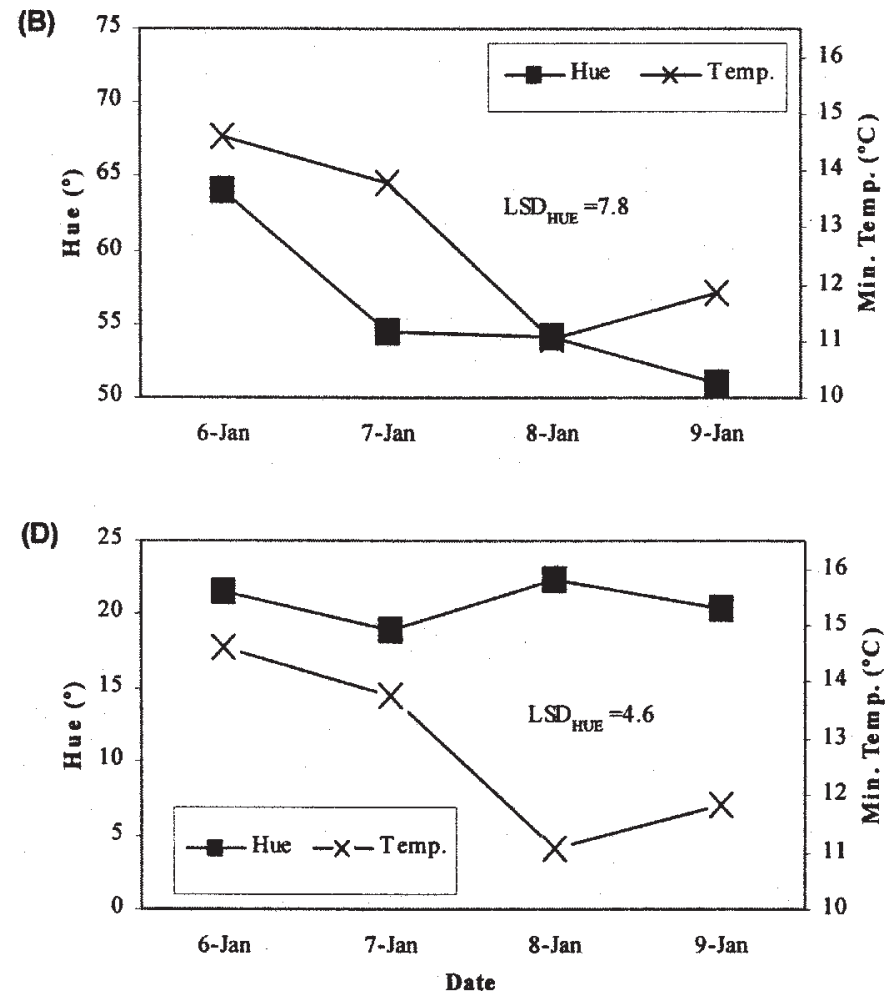

Fig. 7. Phenylalanine ammonia-lyase (PAL) and UDPGal:flavonoid-3-o-glycosyltransferase (UFGT) activity in 'Rosemarie' (A) and 'Bon Rouge' (B) peel during the passing of a cold front (6-9 Jan. 2002). Hue angles and minimum temperatures are also presented in (C) 'Rosemarie' and (D) 'Bon Rouge'. Hue angles, measured at the reddest position on fruit, fluctuate between $0^{\circ}$ (red-purple) and $90^{\circ}$ (yellow). 
Considering that lower minimum temperatures were experienced the week before harvest, the weaker response of 'Rosemarie' color and enzyme activity (Table 3; Figs. 6 and 7) suggests that the fading of red color in maturing fruit cannot only be ascribed to the increasing temperatures typically experienced from anthesis in spring until harvest in mid-summer. It also provides further evidence that, despite the fluctuation in 'Rosemarie' color during fruit development, the ability to synthesize anthocyanin also decreases towards maturity as was more evident in other cultivars (Fig. 2). Furthermore, the increase in redness in response to the second cold front without any significant increase in enzyme activity casts doubt on whether activity of these enzymes regulated anthocyanin synthesis in 'Rosemarie' at this stage of fruit development. The increase in UFGT activity during fruit development was probably sufficient to allow anthocyanin synthesis in response to low temperatures at later stages of fruit development in 'Rosemarie' without requiring any further increase in activity. As in apples (Lister et al., 1996), color development in 'Rosemarie' and 'Bon Rouge' pears was apparently regulated at an enzymatic step preceding UFGT. Since the activity of both PAL and UFGT increased with the passing of the first cold front, reddening at this stage of fruit development apparently entailed the coordinated up regulation and increased flux through the entire anthocyanin biosynthesis pathway. Reddening in response to the second cold front appeared to rely more on the precursor pool as previously found in maturing apple (Ju et al., 1995b).

Considering the good correlation between hue, enzyme activity and low temperatures early during fruit development (Table 3), it was rather surprising that the considerable fluctuation in 'Rosemarie' color over fruit development, especially at early stages, was not reflected in PAL or UFGT activity (Fig. 3). It is possible, however, that enzyme activity might more rapidly return to prefrontal levels than the anthocyanin concentration and red color. Faragher and Chalmers (1977) found that PAL activity increased after a short lag period in whole apples transferred to light at $20^{\circ} \mathrm{C}$ and decreased again after $30 \mathrm{~h}$, but anthocyanin continued to accumulate for a further $100 \mathrm{~h}$. Subjecting apples, precooled at $4{ }^{\circ} \mathrm{C}$, to $30^{\circ} \mathrm{C}$ for 3 h nearly halved subsequent anthocyanin synthesis at $20^{\circ} \mathrm{C}$ (Reay, 1999). The same rapid inhibition of elicitor-induced PAL expression has been observed in parsley cell cultures transferred to 37 ${ }^{\circ} \mathrm{C}$ (Walter; 1989). We did not follow enzyme activity for a long enough period after the passing of cold fronts to verify this.

In conclusion, color development and the fading of color in both 'Rosemarie' and 'Bon Rouge' had an underlying developmental component. In 'Rosemarie', however, environmental regulation of color development was superimposed on the developmental component so that red color development depended on the passing of cold fronts. PAL and UFGT activity did not appear to regulate anthocyanin synthesis in pears, though PAL activity and red color both decreased toward harvest.

\section{Literature Cited}

ARC Infruitec-Nietvoorbij and SAPO. 1998. South African fruit cultivars. Agr. Res. Council, Pretoria, S. Afr.

Boss, P.K., C. Davies, and S.P. Robinson. 1996. Analysis of the expression of anthocyanin pathway genes in developing Vitis vInifera L. cv. Shiraz grape berries and the implications for pathway regulation. Plant. Physiol. 111:1059-1066.

Bradford, M.M. 1976. A rapid and sensitive method for the quantitation of microgram quantities of protein utilizing the principle of protein-dye binding. Anal. Biochem. 72:248-254.

Christie, P.J., M.R. Alfenito, and V. Walbot. 1994. Impact of low-temperature stress on general phenylpropanoid and anthocyanin pathways: Enhancement of transcript abundance and anthocyanin pigmentation in maize seedlings. Planta 194:541-549.

Curry, E.A. 1997. Temperatures for optimal anthocyanin accumulation in apple tissue. J. Hort. Sci. 72:723-729.

Dussi, M.C., D. Sugar, A.N. Azarenko, and T.L. Righetti. 1997. Colorimetric characterization of red pear cultivars. Fruit Var. J. 51:39-43.

Dussi, M.C., D. Sugar, and R.E. Wrolstad. 1995. Characterizing and quantifying anthocyanins in red pears and the effect of light quality on fruit color. J. Amer. Soc. Hort. Sci. 120:785-789.

Faragher, J.D. 1983. Temperature regulation of anthocyanin accumulation in apple skin. J. Expt. Bot. 34:1291-1298.

Faragher, J.D. and D.J. Chalmers. 1977. Regulation of anthocyanin synthesis in apple skin. III. Involvement of phenylalanine ammonia-lyase. Austral. J. Plant Physiol. 4:133-141.

Francis, F.J. 1970. Anthocyanins in pears. HortScience 5:42.

Given, N.K., M.A. Venis, and D. Grierson. 1988. Phenylalanine ammonia-lyase activity and anthocyanin synthesis in ripening strawberry fruit. J. Plant Physiol. 133:25-30.

Harborne, J.B. 1965. Flavonoids: Distribution and contribution to plant colour, p. 247-278. In: T.W. Goodwin (ed.). Chemistry and biochemistry of plant pigments. Academic Press, London, U.K.

Haselgrove, L., D. Botting, R. Van Heeswijck, P.B. Høj, P.R. Dry, C. Ford, and P.G. Iland. 2000. Canopy microclimate and berry composition: The effect of bunch exposure on the phenolic composition of Vitis vinifera L cv, Shiraz grape berries. Austral. J. Grape Wine Res. 6:141-149.

Huysamer, M. 1998. Report of the blushed pear workgroup: Perceptions, facts and questions, p. 187-192. Proc. Cape Pomol. Assn. Tech. Symp., Cape Town, S. Afr., 2-3 June.

Ju, Z., C. Liu, and Y. Yuan. 1995a. Activities of chalcone synthase and UDPGal: flavonoid-3-o-glycosyltransferase in relation to anthocyanin synthesis in apple. Scientia Hort. 63:175-185.

Ju, Z., Y. Yuan, C. Liou, and S. Xin 1995b. Relationships among phenylalanine ammonia-lyase activity, simple phenol concentrations and anthocyanin accumulation in apple. Scientia Hort. 61:215-226.

Ju, Z., C. Liu, Y. Yuan, Y. Wang, and G. Liu. 1999. Coloration potential, anthocyanin accumulation, and enzyme activity in fruit of commercial apple cultivars and their F1 progeny. Scientia Hort. 79:39-50.

Lancaster, J.E., P.F. Reay, J. Norris, and R.C. Butler. 2000. Induction of flavonoids and phenolic acids in apple by UV-B and temperature. J. Hort. Sci. Biotechnol. 75:142-148.

Leyva, A., T.A. Jarillo, J. Salienas, and J.M. Martinez-Zapater. 1995. Low temperature induces the accumulation of phenylalanine ammonia-lyase and chalcone synthase mRNAs of Arabidopsis thaliana in a light-dependent manner. Plant Physiol. 108:39-46.

Lister, C.E., J.E. Lancaster, K.H. Sutton, and J.R.L. Walker. 1994. Developmental changes in the concentration and composition of flavonoids in skin of a red and a green apple cultivar. J. Sci. Food Agr. 64:155-161.

Lister, C.E., J.E. Lancaster, and J.R.L. Walker. 1996. Developmental changes in enzymes of flavonoid biosynthesis in the skins of red and green apple cultivars. J. Sci. Food Agr. 71:313-330.

Macheix, J-J., A. Fleuriet, and J. Billot. 1990. Fruit phenolics, p. 149-237. CRC Press Inc., Boca Raton, Fla.

Marais, E., G. Jacobs, and D.M. Holcroft. 2001. Postharvest irradiation enhances anthocyanin synthesis in apples but not in pears. HortScience 36:738-740.

McClure, J.W. 1975. Physiology and functions of flavonoids, p. 970-1055. In: J.B. Harborne, T.J. Mabry, and H. Mabry (eds.). The flavonoids. Chapman \& Hall Ltd, London, U.K.

McGuire, R.G. 1992. Reporting of objective colour measurements. HortScience 27:1254-1255.

Reay, P.F. 1999. The role of low temperatures in the development of the red blush on apple fruit ('Granny Smith'). Scientia Hort. 79:113-119.

Shvarts, M., A. Borochov, and D. Weiss. 1997. Low temperature enhances petunia flower pigmentation and induces chalcone synthase gene expression. Physiol. Plant. 99:67-72.

Tan, S.T. 1980. Phenylalanine ammonia-lyase and the phenylalanine ammonialyase inactivating system: Effects of light, temperature and mineral deficiencies. Austral. J. Plant Physiol. 7:159-167.

Walter, M.H. 1989. The induction of phenylpropanoid biosynthetic enzymes by ultraviolet light or fungal elicitor in cultured parsley cells is overriden (sic) by a heat-shock treatment. Planta 177:1-8.

Zucker, M. 1965. Induction of phenylalanine deaminase by light and its relation to chlorogenic acid synthesis in potato tuber tissue. Plant Physiol. 40:779-786. 